\title{
KOBIETA JAKO MENEDŻER PRZYSZŁOŚCI
}

\author{
Katarzyna Łukasik, Artur Sawicki \\ Politechnika Częstochowska \\ Wydział Zarządzania
}

\begin{abstract}
Streszczenie: Autorzy artykułu podjęli próbę obalenia stereotypu związanego z wyróżnieniem mężczyzny na stanowisku menedżerskim oraz określenia roli kobiety na stanowisku kierowniczym we współczesnych przedsiębiorstwach. Ponadto wskazano rolę i miejsce menedżera we współczesnej organizacji oraz jakie cechy powinny go szczególnie charakteryzować. W artykule wykorzystano badanie przeprowadzone na ponad stu polskich menedżerkach, zajmujących różne stanowiska kierownicze w przedsiębiorstwie.
\end{abstract}

Słowa kluczowe: kobieta, menedżer, organizacja

DOI: 10.17512/znpcz.2016.2.10

\section{Wprowadzenie}

Analiza rynku pracy i badań zamieszczonych w Internecie oraz innych mediach pozwala dostrzec fakt, że dziś osobom z wykształceniem menedżerskim dość trudno znaleźć pracę. Zmiany, które dokonują się w gospodarce, wskazują na duży popyt na pracowników, których wykształcenie odpowiada wymaganym przez rynek kwalifikacjom. Okazuje się, że niezwykłą trudnością dla pracodawców jest znalezienie osoby, która jest ekspertem w konkretnej dziedzinie. Zatem dobry menedżer stał się obiektem pożądania wielu firm i tym samym rola osób zajmujących się zarządzaniem nabrała wartości. $\mathrm{Z}$ uwagi na to, że świat biznesu kieruje się własnymi zasadami, ciężko znaleźć różnice miedzy kobietą a mężczyzną na stanowiskach menedżerskich. Mimo tego duża liczba przedsiębiorstw z reguły na stanowiska średniego i wyższego szczebla wybiera mężczyzn. Stanowi to niejako stereotyp, według którego płeć męska traktowana jest jako bardziej kompetentna do roli menedżera aniżeli płeć przeciwna.

Celem artykułu jest próba udowodnienia, że kobieta może być równie dobrym, jak nie lepszym menedżerem niż mężczyzna, oraz określenie jej roli we współczesnym zarządzaniu przedsiębiorstwem XXI wieku. W artykule wykorzystano badanie przeprowadzone w 2015 roku wśród stu polskich menedżerek, które zajmowały stanowiska dyrektorów, kierowników, członków zarządu i rad nadzorczych, prezesów oraz właścicieli firm. Badania zostały przeprowadzone przez PricewaterhouseCoopers.

\section{Menedżer i jego miejsce w organizacji}

Rola osób na stanowiskach menedżerskich w przedsiębiorstwach na przestrzeni lat uległa diametralnym zmianom. Dawniej menedżer postrzegany był jako osoba, która ma wskazywać podległemu mu pracownikowi czynność do wykonania i spra- 
wować nad nim kontrolę. Obecnie od menedżera wymaga się, aby jego działania ukierunkowane były także na motywację pracownika do bardziej wydajnej pracy, co skutkować ma efektywniejszą realizacją celów strategicznych przedsiębiorstwa. Literatura definiuje menedżera jako osobę, która zarządza przedsiębiorstwem lub jego częścią za przyzwoleniem właściciela lub dyrektora firmy. Menedżer to również osoba, która pełni funkcje właściciela albo kierownika na różnych szczeblach w firmie (Kubik 2005, s. 71).

Jak wspomniano, współczesny menedżer ma odmienny styl kierowania, wcześniej podwładni traktowali go jako przełożonego, który ma prawo karać (Penc 2007, s. 143). Dziś menedżer musi posiadać predyspozycje do zarządzania pracownikami w całym tego słowa znaczeniu. Ale sama umiejętność kierowania pracownikami nie określa menedżera jako profesjonalistę; prócz odpowiednich umiejętności kierowniczych winien posiadać pożądane cechy charakteru (Sawicki 2014, s. 227). Zdaniem J. Tylki współczesny menedżer musi się charakteryzować (Tylka 2012, s. 12):

- nienagannym wyglądem,

- pewnością siebie,

- umiejętnością tworzenia własnego wizerunku,

- wysoką ambicją,

- orientacją na sukces,

- kreatywnością i asertywnością,

- innowacyjnością,

- tolerancją,

- sprawnością perswazyjnego mówienia i słuchania,

- uporem i stanowczością,

- inteligencją i organizacją pracy.

Z punktu widzenia właściciela, jak i pracowników do ważniejszych zadań menedżera należy tworzenie w pracy dobrej atmosfery, która będzie zapobiegać powstawaniu konfliktów w przedsiębiorstwie i w jego otoczeniu.

Ponadto warte uwagi jest zapoznanie się ze standardami unijnymi z obszaru kształcenia personelu i społecznej odpowiedzialności pracodawców, jako niektórymi kierunkami zarządzania pracownikami.

Menedżer organizacji musi wzbudzać zaufanie wśród współpracowników. Pełniąc funkcję kierowniczą, nie może jej nadużywać, w celu np. manipulacji pracownikami. Od menedżera wymaga się, aby słuchał, rozumiał i elastycznie angażował się w rozwiązywanie powstałych problemów. Aby jego czynności były efektywnie wykonywane, powinien być odporny na sytuacje stresowe (Kiełtyka 2004, s. 103-106; Kielesińska 2009, s. 184-195).

Zdaniem H. Skłodowskiego osoba pełniąca funkcję menedżera powinna być odpowiednio ukształtowana oraz zintegrowana. Cechować się powinna (Skłodowski 1993, s. 24-25):

- trwałością przekonań, dzięki którym możliwe jest wyrażanie własnej opinii w istotnych obszarach,

- charakterem (zespół wartości i przekonań),

- odpowiedzialnością za podejmowane działania, 
- umiejętnościami informacyjnymi (merytoryczność i transparentność przekazywanych informacji),

- sprawiedliwością wobec podwładnych,

- twórczą, samodzielną postawą,

- zrównoważeniem emocjonalnym.

Kobietę $\mathrm{w}$ roli menedżera spotyka się najczęściej w mikro i małych przedsiębiorstwach, które zazwyczaj rozwijają się wolniej niż duże firmy. Pełnienie stanowiska menedżerskiego przez kobietę przyjmuje dwie formy. Pierwsza z nich dotyczy posiadanych umiejętności. Bywa, że kobiety są lepiej wykształcone aniżeli mężczyźni, a mimo to ich brak awansu jest wynikiem dyskryminacji. Z drugiej strony ich sposób zarządzania przedsiębiorstwem różni się od prowadzenia firmy przez mężczyzn (Mukhtar 2002, s. 289-311).

Kobiety pełniące role kierownicze w przedsiębiorstwach są bardziej empatyczne, co wpływa na lepszą komunikację z ludźmi oraz skuteczniejsze zarządzanie zespołem. Z kolei ich pewność siebie jest niższa aniżeli w przypadku mężczyzn, co może oznaczać problemy z podjęciem samodzielnych decyzji w kluczowych momentach funkcjonowania przedsiębiorstwa. Wynikiem tego będzie mniejsze skupienie uwagi na maksymalizacji zysku (Gatewood i in. 2002, s. 187-206).

Zdaniem K. Zięby wzrost liczby kobiet na stanowiskach menedżerskich może spowodować problemy dla przedsiębiorstw, którymi dotychczas zarządzali mężczyźni (Zięba 2010, s. 456). Nadzieję na dowiedzenie, że kobieta może być menedżerem przyszłości, prezentują poniższe wyniki badań.

\section{Analiza wyników badania Kobiety menadżerami przyszłości}

Jako część badawczą wykorzystano badanie przeprowadzone w styczniu 2015 roku przez PricewaterhouseCoopers na grupie ponad 100 menedżerek, które zajmowały stanowiska średniego i najwyższego szczebla w firmie. Wśród nich były właścicielki, dyrektorki, kierowniczki, członkinie zarządu i rady nadzorczej. $60 \%$ respondentek zatrudniało powyżej 250 osób, a $23 \%$ z badanych nie przekroczyło 35. roku życia.

Z badania wynika, że 93\% ankietowanych kobiet jest zdania, że kobieta menedżer wprowadza do stylu zarządzania kompetencje skutecznej komunikacji i efektywnie buduje dialogi oraz relacje z otoczeniem. Ponadto $44 \%$ respondentek uważa, że ma to wpływ na współtworzenie oraz realizację wizji rozwoju firmy. Obecnie przedsiębiorstwa, które chcą być konkurencyjne na rynku i podążać za trendami, powinny uwzględniać rozwijanie tych umiejętności. Bowiem w kobietach może tkwić potencjał w obszarach, w których mężczyźni się nie sprawdzają. Aktualnie firmy stają przed pytaniem: Która płeć będzie skutecznie prowadzić firmę w erze transformacji cyfrowej? Prawdą jest, że dołożą wszelkich starań, aby potencjału kobiet nie zmarnować, lecz maksymalnie go wykorzystać, co może się udać, ponieważ - jak wynika z badania $-62 \%$ badanych kobiet twierdzi, że wierzy w siebie i we własne siły oraz ma świadomość, jakie obszary wymagają z ich strony dopracowania. 


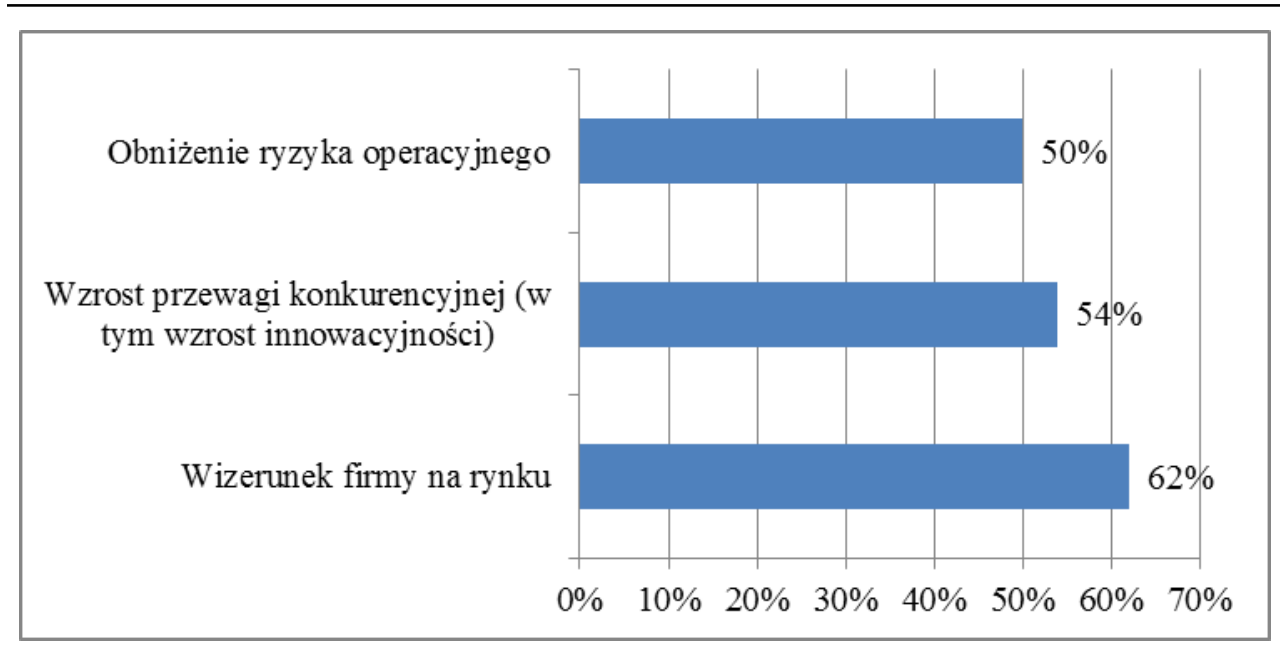

Rysunek 1. Korzyści dla firmy z tytułu zatrudnienia kobiet na stanowiskach menedżerskich

Źródło: (PwC 2015, s. 3)

Ponadto, jak wynika z Rysunku 1, kobiety uważają, że wzrost liczby reprezentantów płci żeńskiej na stanowiskach menedżerskich spowoduje wzrost przewagi konkurencyjnej (62\%), w tym wzrost samej innowacyjności (54\%) i spadek podejmowanego ryzyka operacyjnego (50\%). Z badania wynika również, że kobiety dynamiczniej i bardziej efektownie aspirują do uzyskiwania wyższych standardów niż mężczyźni.

Dodatkowo menedżerki chętnie biorą udział w seminariach, konferencjach, nie marnując czasu podczas networkingu. Badania pokazują, że $60 \%$ kobiet za istotne uważa budowanie relacji $\mathrm{z}$ otoczeniem oraz wymianę wiedzy i doświadczenia. Zdobywanie wiedzy powoduje wiarę we własne siły i pewność siebie. To pozytywny aspekt dla rynku pracy, ponieważ budowanie sieci kontaktów promuje indywidualne idee i wartości kobiecego zarządzania. Rozumieć tu należy, że kobiety chętnie się uczą, zdobywają doświadczenie, ale i chętnie się tym dzielą, nawet między osobami w branży, bowiem dla $41 \%$ badanych kobiet istotne jest wsparcie merytoryczne, jakie otrzymują od znajomych i współpracowników. Ta informacja utwierdza w przekonaniu, że kobietom należy stwarzać warunki, podczas których będą one mogły zdobywać wiedzę i kontakty międzyludzkie.

Warto zaznaczyć, jak ważną rolę dla kobiet w zarządzaniu spełnia mentoring. Aby tworzyć efektywną współpracę w przedsiębiorstwie, istotne jest nie tylko nauczanie, ale i wiedza, czy dane czynności są prawidłowo wykonywane. $\mathrm{Z}$ badania wynika, że tylko dla $1 \%$ respondentek nieistotna jest informacja zwrotna. Natomiast ponad połowa badanych kobiet oczekuje od kierownictwa informacji o jakości i wydajności wykonywanej pracy. Spoglądając natomiast na rynek pracy, na którym pojawia się młode pokolenie, które niewątpliwie jest pokoleniem nowych technologii, daje się zauważyć, że częstszymi użytkownikami tych urządzeń są mężczyźni. Ale jeśli sytuacja wymaga szybkiej komunikacji w relacjach zawodo- 
wych, to zarówno kobiety, jak i mężczyźni przyznają, że w pierwszej kolejności wykorzystują nowoczesne technologie - głównie urządzenia mobilne. Natomiast jeśli zachodzi potrzeba rozwoju zawodowego, planowania kariery, wówczas kontakty bezpośrednie są częściej wykorzystywane. Kobiety zazwyczaj nieprzerwanie pracują nad swoimi umiejętnościami, dopracowują je, szukają nowych obszarów, które byłyby im przydatne w realizowaniu kariery. Stąd potrzeba, aby w przedsiębiorstwie była osoba, która będzie wskazywać im kierunki. Ponad 90\% respondentek jest przekonanych, że posiadanie mentora w pracy, jak i w życiu, ułatwia realizację celów oraz pomaga w karierze.

PricewaterhouseCoppers od lat śledzi poczynania młodego pokolenia na rynku pracy. Mając na uwadze poglądy, oczekiwania i wartości tej generacji, uwagę należy skierować na ich cechy charakterystyczne, które nie tylko mogą być potrzebne w przedsiębiorstwie, ale i na bieżąco będą zmieniać rynek pracy, a tym samym funkcjonowanie przedsiębiorstw.

Przedstawicielki młodego pokolenia milenialsów (Y) głównie charakteryzuje duża aktywność na rynku, widoczniej niż w przypadku poprzednich generacji. Ponadto są pewne siebie i wierzą we własne umiejętności. Jednak różnice międzypokoleniowe dostrzega się również w wykształceniu. Kobiety na świecie są coraz lepiej wykształcone, co potwierdza fakt, że w 93 krajach wśród studentów jest więcej kobiet aniżeli mężczyzn.

Ponad połowa badanych kobiet jest pewna, że sprosta wymaganiom stawianym przez pracodawców, jeśli otrzyma możliwość awansu na stanowiska menedżerskie. Dla porównania: o 10 punktów procentowych więcej takich odpowiedzi udzielą mężczyźni. Kwestią najważniejszą jest to, że nowe pokolenie na rynek wnosi niespotykane dotąd wartości oraz inną jakość. Należy zaznaczyć, że poprzednie pokolenia nie były tak ambitne, otwarte, tolerancyjne i nie skupiały się tak bardzo na jakości życia i uzyskiwaniu nowych doświadczeń. Ta ewolucja umożliwiła kobietom zaistnienie $\mathrm{w}$ środowisku menedżerskim na przykład poprzez umiejętność dzielenia ról życiowych i zawodowych. PwC w globalnym ujęciu informuje, że kobiety są na tyle zdeterminowane, że podjęcie pracy na zagranicznym rynku nie stanowi dla nich problemu - tak uważa blisko $70 \%$ menedżerek. $Z$ kolei $63 \%$ jest zdania, że praca na zagranicznym rynku pozawala uzyskać rzadkie umiejętności i stanowi klucz do osiągnięcia sukcesu w zarządzaniu. Mimo to cały czas istnieją działy w firmach oraz zawody, gdzie liczba kobiet jest niższa niż mężczyzn.

Polskie menedżerki wskazują, że do specyficznych branż należy zaliczyć górnictwo, obronność i energetykę, ale 40\% respondentek zaznacza, że jest gotowa rozpocząć karierę menedżerską w każdym sektorze. Inspiracją dla $62 \%$ badanych kobiet jest różnorodność płci. Przez to należy rozumieć, że firmy, które realizują politykę gender diversity, będą lepiej postrzegane przez kobiety i chętniej wybierane jako miejsce realizacji kariery zawodowej. Ale większe zainteresowanie ankietowanych dotyczy zapewnienia przez firmę równowagi w życiu osobistym i zawodowym - takiego zdania jest $93 \%$ badanych kobiet. 


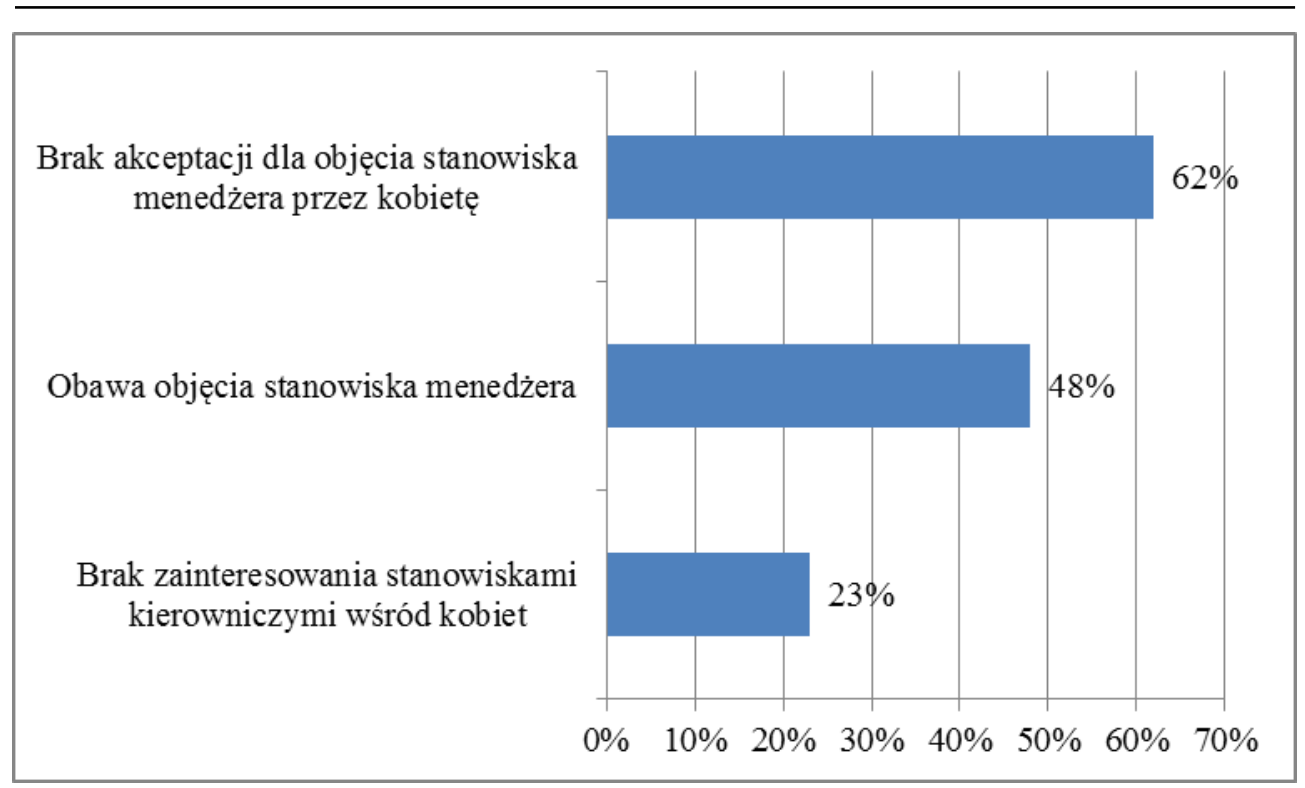

Rysunek 2. Przyczyny braku pełnienia przez kobiety stanowisk menedżerskich

Źródło: (PwC 2015, s. 8)

Pomimo tych znaczących różnic miedzy kobietami a mężczyznami w zarządzaniu i korzyści, jakie przedsiębiorstwo może otrzymać dzięki „kobiecemu przywództwu", oraz relatywnie rosnącej liczbie kobiet w biznesie, wciąż wskaźnik zatrudnienia kobiet jest niższy w porównaniu z zatrudnieniem mężczyzn. Ponadto, jak wynika z Rysunku 2, 23\% badanych menedżerek nie jest zainteresowanych stanowiskami menedżerskimi, a $48 \%$ ma wobec nich obawy. $Z$ kolei ten problem nie zależy tylko od kobiet, ponieważ - jak uważa $62 \%$ ankietowanych - wynika on $\mathrm{z}$ braku akceptacji kobiet na stanowiskach menedżerskich przez osoby zarządzające firmami.

Po raz kolejny PwC informuje, że firmy coraz częściej stawiają na różnorodność płci, ale w dalszym ciągu faworyzują płeć męską - tak uważa co trzecia kobieta $\mathrm{w}$ firmie. Natomiast aż 55\% kobiet dostrzega, że firmy mają na uwadze różnorodność płci, ale nie dostrzegają wielkich zmian, które by tę politykę realizowały. $Z$ kolei trzy czwarte polskich menedżerek widzi pozytywne zmiany związane ze wzrastającą liczbą kobiet na stanowiskach menedżerskich, ale $24 \%$ pań nadal tych zmian nie dostrzega i ta liczba wskazuje, że do zachodnich państw polskim przedsiębiorstwom jeszcze daleko, choć zmiany są widoczne.

Polskie menedżerki nadal za istotne wskazują work-life balance (65\%). Kobiety na stanowiskach kierowniczych nierzadko muszą wybierać pomiędzy pracą a rodziną i życiem towarzyskim, gdzie to ostanie i tak jest coraz rzadziej brane pod uwagę. Z badania wynika, że ponad połowa kobiet realizująca karierę zawodową musiała w dużym stopniu ograniczyć czas na własne zainteresowania, a $40 \%$ ankietowanych kobiet - na życie towarzyskie. 
Polskie menedżerki w badaniu przedstawiają, jakich umiejętności może brakować kobietom w organizacjach. Ponad $60 \%$ ankietowanych uważa, że brakuje im wiary we własne kompetencje, a $46 \%$ jest zdania, że boją się podjąć ryzyko. Analiza obaw kobiet pozwala uzyskać wiedzę na temat lęków i trudności, jakie napotykają w swojej karierze zawodowej. Pomoc kobietom w rozwiązaniu tych problemów może ukazać, jakimi predyspozycjami kobiety dysponują. Warte uwagi jest to, iż co piąta menedżerka uważa, że na stanowiskach kierowniczych kobietom nie brakuje żadnych kompetencji w porównaniu z mężczyznami. A ponadto $74 \%$ z nich widzi, że udział kobiet na stanowiskach średniego i najwyższego szczebla wzrasta. Potencjał kobiet w zarządzaniu dostrzegł Parlament Europejski. W 2012 roku rozpoczęto dyskusje nad rolą kobiet w organach decyzyjnych przedsiębiorstw funkcjonujących w krajach UE. Wynikiem tego $\mathrm{w}$ listopadzie następnego roku zatwierdzono do realizacji projekt, który ma zwiększyć rolę kobiet w organizacjach. Skutkiem tego projektu był wzrost liczby kobiet na stanowiskach kierowniczych średnio o około 4\% w latach 2013-2014. W Wielkiej Brytanii wzrost oscylował w granicach 5 punktów procentowych. Ingerencja UE umożliwia kobietom łatwiejsze osiąganie sukcesów i realizowanie kariery zawodowej. Badania utwierdzają właścicieli firm w domniemaniach, że rynek potrzebuje utworzenia nowego modelu kompetencji przywódczych. Model ten będzie bazował między innymi na umiejętnościach kobiet. Niezbędna w tym zakresie będzie realizacja polityki firm, która powinna wspierać przyszłe menedżerki.

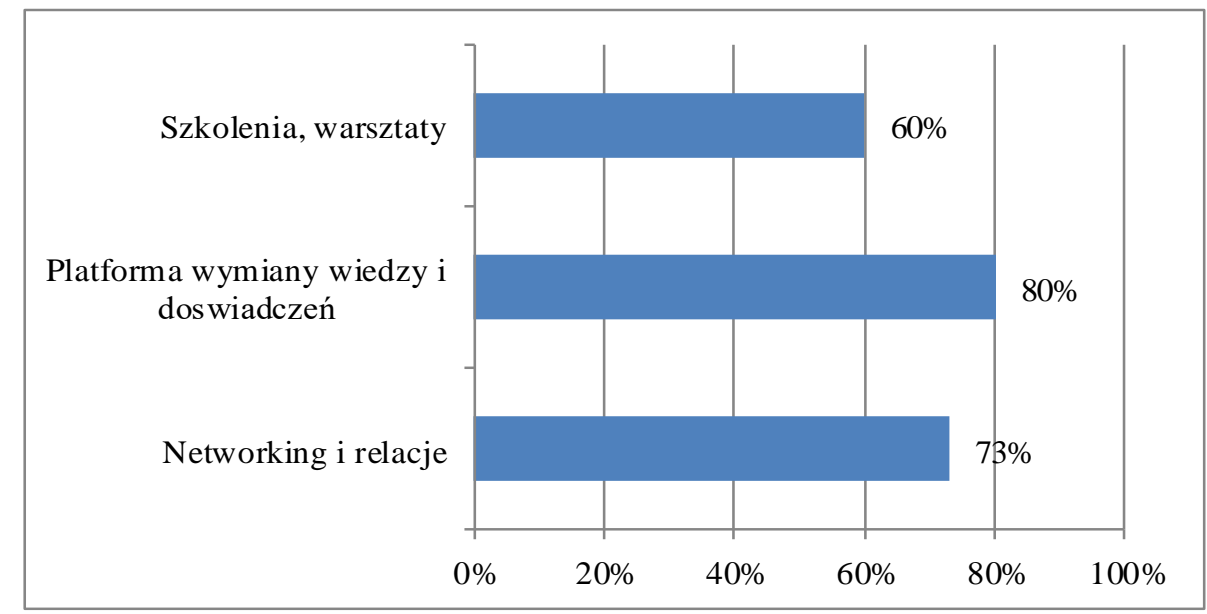

\section{Rysunek 3. Podstawowe elementy budowania wspólczesnego modelu} kompetencji przywódczych względem kobiet

Źródło: (PwC 2015, s. 10)

Jak twierdzą same respondentki (co przedstawiono na Rysunku 3), głównie potrzebują one inicjatyw, za pośrednictwem których będą rozwijać umiejętności, pozyskiwać wiedzę i dzielić się doświadczeniami - takiego zdania jest $80 \%$ badanych - a ponadto budować relację (73\%) i podnosić kwalifikację poprzez oferowanie szkoleń $(60 \%)$. 
Badanie, na które powołują się autorzy artykułu, precyzyjne obrazuje silne i mocne strony kobiet. Przedstawia obraz kobiety menedżerki, który nie może zostać zbagatelizowany przez współczesne firmy chcące się rozwijać na rynku.

$Z$ kolei inne badanie przeprowadzone wśród 500 polskich menedżerów dowodzi, że według $63 \%$ z nich płeć nie ma wpływu na skuteczność pracy, a zdaniem $58 \%$ nie wpływa na osiągnięcia zawodowe. Nie oznacza to jednak, że istnieje brak różnicy pomiędzy kobietami a mężczyznami na stanowiskach menedżerskich. Według badanych menedżerki są nastawione na dokładność wykonywanych zadań i na współpracę z zespołem, podczas gdy mężczyźni są bezwzględni w realizacji celu, szybko podejmują decyzje, są skłonni do ryzyka i wykazują zdolności przywódcze. Mimo to respondenci uważają, że żadna z powyższych cech nie dyskwalifikuje danej płci na stanowisku kierowniczym. Ponieważ płeć nie jest tak bardzo istotna jak sposób wykonywanej pracy, umiejętności interpersonalne czy umożliwianie podwładnym twórczego i kreatywnego myślenia, a także inspirowanie zespołu do wydajniejszej pracy. Zdaniem 34\% badanych za osiągnięcie sukcesu na stanowisku kierowniczym odpowiedzialne są cechy biologiczno-społeczne. O 2 punkty procentowe więcej respondentów jest przekonanych, że dobry menedżer może być przedstawicielem tylko jednej płci. Blisko $60 \%$ badanych uważa, że lepszym menedżerem jest mężczyzna. Z kolei $20 \%$ respondentek jest zdania, że kobieta lepiej niż mężczyzna wykonuje powierzone obowiązki ${ }^{1}$.

Natomiast firma Deloitte przeprowadziła badanie, którego celem było poznanie struktury tworzenia władzy $\mathrm{w}$ przedsiębiorstwach przez kobiety i mężczyzn. $\mathrm{Z}$ badania wynika, że kobiety tworzą i gruntują w przedsiębiorstwach pozycję za pośrednictwem współpracy z innymi pracownikami, konsultując się, prezentując im własne stanowisko i tym samym prosząc opinię. Mimo że jest to czasochłonne, to nawiązane dzięki temu relacje są trwałe i stanowią podstawę do tworzenia np. kultury organizacyjnej. $22 \%$ badanych zdecydowanie preferuje mężczyznę jako zwierzchnika, a tylko $8 \%$ widzi w tej roli kobietę. Natomiast dla blisko $70 \%$ płeć menedżera nie ma żadnego znaczenia, a 63\% jest zdania, że mężczyznom o wiele łatwiej awansować aniżeli kobietom² ${ }^{2}$.

\section{Podsumowanie}

Firmy w XXI w wieku, dążące do efektywnego prowadzenia biznesu, powinny rozważyć udział kobiet w zarządach i radach nadzorczych. Kompetencje, jakie posiadają kobiety, już dziś powinny zwrócić uwagę właścicieli firm, bowiem wartości i umiejętności posiadanych przez kobiety nie powinno się lekceważyć. Obecnie dostrzega się trend $\mathrm{w}$ kierunku intensyfikacji zajmowania przez kobiety stanowisk na najwyższych i średnich szczeblach firm. Oceniając potencjał kobiet względem ich

\footnotetext{
${ }^{1}$ Badanie przeprowadziła firma Diners Club pod patronatem PKPP Lewiatan na 500 polskich menedżerach w ramach programu Talent Club pt. Wojna ptci, http://kariera.pb.pl/2507463,88172,badaniekobieta-menedzer-rownie-skuteczna-jak-mezczyzna (dostęp: 18.06.2016)

${ }^{2}$ Badanie firmy Deloitte przeprowadzono w czerwcu i w lipcu 2012 roku na 242 menedżerach (131 kobiet i 111 mężczyzn) w największych polskich przedsiębiorstwach z różnych branż. http://www.fronda.pl/a/kobieta-lepszym-szefem-niz-mezczyzna,22957.html (dostęp: 18.06.2016).
} 
stanowisk pracy, zauważa się, że mogą stanowić one ważny czynnik konkurencyjny firmy na rynku. Stąd zasadne jest wykorzystanie przez autorów badania, które przybliżyło aspekty karier zawodowych wśród kobiet i doprowadziło do obalenia stereotypu wyjątkowości mężczyzn na stanowiskach kierowniczych.

Autorzy artykułu nie mają wątpliwości, że nadal na stanowiskach kierowniczych liczba kobiet jest niska, mimo jej systematycznego wzrostu. PwC prognozuje, że w 2040 roku kobiet na stanowiskach menedżerskich będzie w ogólnej liczbie $30 \%$. Widoczny jest w Polsce społeczny trend, który umożliwia kobietom zabieganie o te stanowiska na równi z mężczyznami. Głównie dlatego, że zmienia się model przywództwa. Współczesne liderki charakteryzują się bardzo dobrymi umiejętnościami komunikacyjnymi i zdolnościami dochodzenia do kompromisu oraz elastycznością, a tego potrzeba przedsiębiorstwom funkcjonującym na niestabilnych rynkach.

Warto zaznaczyć, że kobiety lepiej od mężczyzn czerpią korzyści z networkin$g u$. Bowiem - jak wynika z badania - dla $60 \%$ badanych menedżerek istotne jest budowanie trwałych relacji oraz wymiana wiedzy i doświadczeń. Dużą rolę w uzyskiwaniu doświadczeń odgrywa mentoring. Badanie wskazało, że kobiety lubią być oceniane przez przełożonych, ale i też doceniane. Lepiej nabywają doświadczenia, jeśli na początku kariery zawodowej mentor pomaga im wytyczać kierunek rozwoju. Z badania wynika także, że kobiety mają słabą wiarę we własne siły i obawiają się podjęcia wyzwania awansu. Dlatego istotna jest rola mentora, który od samego początku będzie wspierał przyszłe menedżerki w rozwoju kariery zawodowej.

Autorzy artykułu sugerują, aby w przypadku młodych menedżerek rolę mentora pełniła kobieta. Przyczyną tego jest zachowanie równowagi między pracą a życiem osobistym. Z uwagi na fakt, że kobiety są najczęściej pochłonięte obowiązkami rodzinnymi, lepiej będą potrafiły przekazać idee work-life balance. Praktyczne porady i wskazówki stanowią kluczowe informacje dla kobiet rozpoczynających karierę zawodową. Dla menedżerek istotne jest również, w jaki sposób przyszły pracodawca realizuje politykę różnorodności płci. Już po pierwszych kontaktach bezpośrednich z właścicielami firm potrafią dostrzec, czy polityka różnorodności płci na stanowiskach kierowniczych jest w pełni realizowana, czy są to tylko deklaracje bez pokrycia.

Warto wspomnieć, iż w części badawczej wyraźnie zaznaczono, że mimo realizacji tej polityki przez przedsiębiorstwa, nadal jako kandydaci na te stanowiska faworyzowani są mężczyźni ${ }^{3}$. Być może przyczynę takiej sytuacji stanowi fakt, iż kobiety dość często, kiedy otrzymują propozycję pracy na stanowiskach menedżerskich, w pierwszej kolejności myślą, jakich umiejętności może im brakować do prawidłowego wykonywania powierzonych czynności. Ale należy brać pod uwagę nie tylko stopień ciężkości wykonywanej pracy, która jest od zawsze przypisywana płci męskiej, ale i otwieranie się na nowe możliwość. Być może ukryty potencjał kobiet będzie stanowić nową jakość przedsiębiorstwa, które stanie się liderem na rynku pod względem konkurencyjności i nowoczesności firmy.

\footnotetext{
${ }^{3}$ Potwierdza to ranking z 2013 roku, gdzie na czołowych miejscach, żadna kobieta nie zajmuje najwyższego stanowiska, http://500menedzerow.pb.pl/staticpage/laureaci2013 (dostęp: 18.06.2016) .
} 
Firmy na rynku europejskim deklarują wzrost liczby kobiet na średnich i najwyższych szczeblach, dzięki projektowi Parlamentu Europejskiego z 2013 roku, który to nakazuje zwiększenie roli kobiet w organizacjach poprzez ich udział w zarządach i radach nadzorczych. Takie wsparcie dla kobiet wywiera na przedsiębiorstwach budowanie nowego modelu przywództwa. To ogromne wyzwanie dla współczesnych przedsiębiorstw, które zdaniem polskich menedżerek powinny dążyć do tworzenia miejsc/wydarzeń, gdzie kobiety mogłyby nabywać wiedzę i doświadczenia oraz budować długotrwałe relacje z otoczeniem. Zakłada się, że inwestycja w rozwój zawodowy i osobisty prowadzi do sukcesu, zarówno samego pracownika, jak i pracodawcy.

\section{Literatura}

1. Gatewood E.J., Shaver K.G., Powers J.B., Gartner W.B. (2002), Entrepreneurial Expectancy, Task Effort, and Performance, "Entrepreneurship Theory and Practice", Vol. 27, Issue 2, s. 187-206.

2. Gołąb S., Kucharski A. (2013), Kompetencje menedżerów w procesie oceny i motywowania pracowników, „Folia Pomeranae Universitatis Technologiae Stetinensis”, seria Oeconomica nr 301(71), s. 35-42.

3. http://kariera.pb.pl/2507463,88172,badanie-kobieta-menedzer-rownie-skuteczna-jakmezczyzna (dostęp: 18.06.2016).

4. http://www.fronda.pl/a/kobieta-lepszym-szefem-niz-mezczyzna,22957.html (dostęp: 18.06.2016).

5. http://www.pwc.pl/pl/media/2015/2015-03-06-kobiety-w-biznesie.html (dostęp: 01.04.2016).

6. Kielesińska A. (2009), Aspekt osobowości menedżera w zarządzaniu, [w:] Bylok F., Harciarek M. (red.), Psychologiczne i socjologiczne aspekty zarządzania zasobami ludzkimi, Wydawnictwo Politechniki Częstochowskiej, Częstochowa.

7. Kiełtyka L. (2004), Czynniki stresogenne u menedżera, [w:] Szopa J., Harciarek M. (red.) Stres i jego modelowanie, Sekcja Wydawnictw Wydziału Zarządzania Politechniki Częstochowskiej, Częstochowa.

8. Kubik M. (2005), Menedżer w przedsiębiorstwie przyszłości, TNOiK „Dom Organizatora”, Toruń.

9. Mukhtar S.-M. (2002), Differences in Male and Female Management Characteristics: A Study of Owner-Manager Businesses, "Small Business Economics", No. 18, s. 289-311.

10. Penc J. (2007), Nowoczesne kierowanie ludźmi. Wywieranie wplywu i współdziałanie $w$ organizacji, Difin, Warszawa.

11. PwC (2015), Kobiety menedżerami przyszłości. Wyzwania w skutecznym ksztaltowaniu liderek, PricewaterhouseCooper.

12. Sawicki A. (2014), Wizerunek menedżera - determinanty profesjonalnego wygladu profesjonalizm w skutecznym zarządzaniu, [w:] Kulej-Dudek E., Pypłacz P., Smoląg K. (red.), Rozwój i doskonalenie funkcjonowania organizacji. Aspekty teoretyczne i praktyczne, $\mathrm{Wy}-$ dawnictwo Politechniki Częstochowskiej, Częstochowa.

13. Skłodowski H. (1993), Osobowościowe wyznaczniki działalności kierowniczej, [w:] Witkowski J. (red.), Psychologiczne wyznaczniki sukcesu w zarządzaniu, Zeszyty Naukowe Uniwersytetu Wrocławskiego, Wrocław, s. 24-25.

14. Tylka J. (2012), Zdrowie menedżera. Styl życia a zdrowie i choroba, Difin, Warszawa.

15. Zięba K. (2010), Pteć właściciela/menedżera jako czynnik ksztattujacy rozwój małej firmy aspekty teoretyczne $i$ wyniki badań empirycznych, ,Zeszyty Naukowe Uniwersytetu Szczecińskiego", nr 585, Ekonomiczne Problemy Usług, nr 50: Strategie zarzadzania mikro i matymi przedsiębiorstwami. Mikrofirma 2010, Bielawska A., Szopa A. (red.), Wydawnictwo Naukowe Uniwersytetu Szczecińskiego, Szczecin. 


\section{WOMAN AS A FUTURE MANAGER}

Abstract: Authors of the article has made an attempt to demolish a stereotype related to distinguishing a man on a managerial position, and specification of woman's role on the same vacate in contemporary enterprises. Furthermore, there was a role and place of the manager pointed in a contemporary organization, together with the features that should characterize such persons. The article utilizes the research carried out on more than a hundred managers, occupying various managerial positions in the enterprise.

Keywords: manager, organization, women 